\section{RMD Open}

Rheumatic \&

Musculoskeletal Diseases

\title{
Association between diabetes mellitus and osteoarthritis: systematic literature review and meta-analysis
}

\author{
Karine Louati, ${ }^{1,2,3}$ Céline Vidal, ${ }^{1,2}$ Francis Berenbaum, ${ }^{1,2,3,4}$ Jérémie Sellam ${ }^{1,2,3,4}$
}

To cite: Louati $\mathrm{K}$, Vidal $\mathrm{C}$, Berenbaum $\mathrm{F}$, et al. Association between diabetes mellitus and osteoarthritis: systematic literature review and meta-analysis. $R M D$ Open 2015;1:e000077. doi:10.1136/rmdopen-2015000077

- Prepublication history and additional material is available. To view please visit the journal (http://dx.doi.org/ 10.1136/rmdopen-2015000077).

Received 26 January 2015 Revised 16 March 2015 Accepted 17 March 2015

\section{(1) crossuatk}

${ }^{1}$ Department of Rheumatology, Assistance Publique-Hôpitaux de Paris (AP-HP), Saint-

Antoine Hospital, Paris, France

${ }^{2}$ Inflammation-

Immunopathology-Biotherapy Department (DHU i2B), Paris, France

${ }^{3}$ Sorbonne Universités, UPMC Univ Paris 06, Paris, France

${ }^{4}$ Faculté de Médecine Saint Antoine, INSERM UMR_S 938, Paris, France

Correspondence to Professor Francis

Berenbaum;

francis.berenbaum@sat. aphp.fr

\section{ABSTRACT}

Objectives: To investigate the prevalence of osteoarthritis $(\mathrm{OA})$ in patients with diabetes mellitus (DM) and prevalence of DM in patients with $O A$ and whether $\mathrm{OA}$ and $\mathrm{DM}$ are associated.

Design: A systematic literature review and metaanalysis. We included cohort, case-control and crosssectional studies assessing the number of patients with $\mathrm{DM}$ and/or OA. The mean prevalence of OA among patients with DM and DM among patients with $O A$ was calculated. Data from trials assessing an association of diabetes and $\mathrm{OA}$ were pooled and results are presented as unadjusted $\mathrm{OR}$ and $95 \% \mathrm{Cl}$.

Results: From the 299 publications, we included 49 studies in the analysis, including 28 cross-sectional studies, 11 cohort studies and 10 case-control studies. In all, 21, 5 and 23 articles involved patients with $O A$ exclusively, patients with DM and the general population, respectively. For 5788 patients with DM, the mean $O A$ prevalence was $29.5 \pm 1.2 \%$. For 645089 patients with $\mathrm{OA}$, the prevalence of DM was 14.4 $\pm 0.1 \%$. The risk of $\mathrm{OA}$ was greater in the DM than nonDM population ( $\mathrm{OR}=1.46$ (1.08 to 1.96$), \mathrm{p}=0.01$ ), as was $\mathrm{DM}$ in the $\mathrm{OA}$ than non-OA population $(\mathrm{OR}=1.41$ (1.21 to 1.65), $p<0.00001$ ). Among the 12 studies reporting an OR adjusted on at least the body mass index, 5 showed no association of DM and $\mathrm{OA}$ and 7 identified DM as an independent risk factor.

Conclusions: This meta-analysis highlights a high frequency of $\mathrm{OA}$ in patients with $\mathrm{DM}$ and an association between both diseases, representing a further step towards the individualisation of DM-related $\mathrm{OA}$ within a metabolic $\mathrm{OA}$ phenotype.

\section{INTRODUCTION}

Osteoarthritis (OA) is the most frequent and disabling joint disease in adults. Besides its several localisations, a recent hypothesis has suggested a new classification for phenotyping OA that includes ageing, metabolic syndrome (MetS) and post-traumatic events and genetic-related OA. ${ }^{2}$ Despite some shared pathophysiological mechanisms among these phenotypes, each may display specific pathways.

\section{Key messages}

What is already known on this subject?

- Metabolic syndrome and osteoarthritis have been found to be associated in some studies, delineating the metabolic osteoarthritis phenotype. Association between diabetes mellitus and osteoarthritis in epidemiological studies have given conflicting results.

What does this study add?

- This is the first meta-analysis showing an association between osteoarthritis and diabetes mellitus.

How might this impact on clinical practice?

- Treating diabetes mellitus may be effective in patients with osteoarthritis.

- Prevention initiatives of osteoarthritis may be specifically proposed to patients with diabetes mellitus.

In MetS-associated OA, the mechanical impact of overweight or obesity on joints may easily explain knee OA. However, within this phenotype, considering the epidemiological association of overweight or obesity and hand $\mathrm{OA}$, some systemic factors may participate in the pathogenic process; for example, adipose tissue products, or 'adipokines', may have a systemic impact at a distance on joints. ${ }^{3-5}$ Beyond obesity-related OA, MetS and OA have been found to be associated in some epidemiological studies, which suggests that the other components of MetS, such as diabetes mellitus (DM), high blood pressure or dyslipidaemia may together or independently participate in the OA pathophysiology. ${ }^{6}$ Along this line, DM and hyperglycaemia seemed to be associated with $\mathrm{OA}$ in some epidemiological studies. ${ }^{8-11}$ Moreover, the link between the two diseases may be supported by the deleterious role of glucose excess through the accumulation of advanced glycation end products (AGEs), oxidative stress and promotion of systemic inflammation. ${ }^{12-15}$ This situation 
is well illustrated by spontaneous cartilage disruption in the rat model of streptozotocin-induced diabetes. ${ }^{12-15}$ However, other publications have questioned the link between DM and OA. ${ }^{16} 17$

To further address the association of OA and DM, we performed a systematic review of the literature and a meta-analysis to investigate the prevalence of $\mathrm{OA}$ among patients with DM and that of DM among patients with $\mathrm{OA}$ and to determine whether $\mathrm{DM}$ and $\mathrm{OA}$ are associated.

\section{METHODS}

Systematic literature search and selection of relevant studies

We performed a systematic review of the literature according to the Cochrane guidelines (http://handbook. cochrane.org/, 24 February 2014, date last accessed). Relevant publications were selected from three databases (PubMed, EMBASE and the Cochrane Library) without any limitation on time (up to June 2013 and updated in January 2015). We also searched for articles in the references of selected publications and the main congresses of rheumatology for OA (American College of Rheumatology (ACR), European League Against Rheumatism (EULAR) and Osteoarthritis Research Society International (OARSI)) and congresses of endocrinology (Endocrine society's annual meeting, European Congress of Endocrinology, American Diabetes Association and European Association for the Study of Diabetes) from 2012 to 2014. We used the following key words for the PubMed search: ("diabetes mellitus, type 2" $[\mathrm{MeSH}]$ OR "diabetes mellitus, type 1 ”[MeSH] OR "diabetes complications" $[\mathrm{MeSH}]$ OR "metabolic syndrome $\mathrm{X}$ "[MeSH] OR ("blood glucose" [MeSH] OR "blood glucose"[All Fields])) AND "osteoarthritis" [MeSH] AND ("humans"[MeSH] AND (English[lang] OR French [lang])).

We included observational studies (ie, cohort, casecontrol and cross-sectional studies) assessing the number of patients with $\mathrm{OA}$ and/or DM, or the incidence or prevalence of OA in patients with DM or DM in patients with OA, or an association between OA and DM. We excluded articles of therapeutic studies, reviews and case reports as well as letters; studies in which all patients had OA and DM or in which the link between $\mathrm{OA}$ and DM was not reported; and studies without an available number of patients with each disease. Selection of articles was based on titles and abstracts than on the full text. One author (KL) has managed this selection.

\section{Data extraction}

Two authors (KL and CV) extracted the following data: study design and population (observational study, quality score, definition of DM and OA and localisation of OA); exposure glycaemia (fasting blood glucose (FBG) level, $\mathrm{mmol} / \mathrm{L}$ ) or glycosylated haemoglobin (HbAlc; \%) or number of patients with DM; outcome (number of patients with $\mathrm{OA}$ ); body mass index (BMI, $\mathrm{kg} / \mathrm{m}^{2}$ ) or number of patients with obesity as potential confounders; association measure (relative risk or OR or only conclusion on an association). Then we conversely considered $\mathrm{OA}$ as an exposure factor and $\mathrm{DM}$ as an outcome. The study quality was assessed by the Strengthening the Reporting of Observational Studies in Epidemiology (STROBE) scale and results are reported as a percentage of 19 pertinent items of the 22 total items. $^{18}$

\section{Statistical analysis}

We performed two analyses with available results from trials. First, we performed a descriptive analysis: for cross-sectional, case-control or cohort studies, we used the number of patients with $\mathrm{OA}$ or DM and total number in each population to calculate the prevalence of OA among patients with DM and that of DM among patients with OA. To estimate this prevalence from cohort longitudinal prospective studies, we used baseline data. Prevalence is expressed as mean \pm SD. Second, we performed a comparative analysis using studies assessing an association between diagnosis of DM and $\mathrm{OA}$ in cross-sectional studies and cohort studies of the general population and case-control studies of OA or DM populations. We calculated the odds of having OA among patients with DM and of DM among patients with OA with ORs and 95\% CIs. Then we used Revman V.5.2 to perform a meta-analysis with a fixed-effects model. A random-effects model was used with high heterogeneity among studies $(>50 \%)$, evaluated by $\mathrm{I}^{2}$, and a sensitivity analysis was performed by removing studies with aberrant results and combining studies with the same characteristics. $\mathrm{OR}>1$ and $\mathrm{p} \leq 0.05$ was considered an increased risk of OA among patients with DM and/or DM among patients with OA.

\section{RESULTS}

Literature search and characteristics of included trials

The selection of articles is in figure 1: from 299 publications, we included 49 in the analysis. We found no publication bias (see online supplementary figure S1). The articles represented 28 cross-sectional, 11 cohort and 10 case-control studies. In total, 21, 5 and 23 involved exclusively patients with $\mathrm{OA}$, exclusively patients with DM and the general population, respectively (table 1 ).

The criteria of inclusion for the general population were variable for age: from 20 to 86 years for the Iwaki Health Promotion Project, ${ }^{20}$ and from 65 to 84 years for the ILSA study; ${ }^{46}$ the patients had radiographs of hips for the study of Typpo, ${ }^{31}$ or data were extracted from public service data for the study of Navarro et al. ${ }^{34}$ In most cases, OA was defined by radiological and clinical criteria, usually based on the ACR criteria. DM was defined by elevated glycaemia, HbAlc proportion or prescription of DM treatment (table 2). 
Figure 1 Flow chart of selection of articles. OA, osteoarthritis; DM, diabetes mellitus; RA, rheumatoid arthritis; MetS, metabolic syndrome; CV, cardiovascular; ACR, American College of Rheumatology; EULAR, The European League Against Rheumatism; OARSI, Osteoarthritis Research Society International.

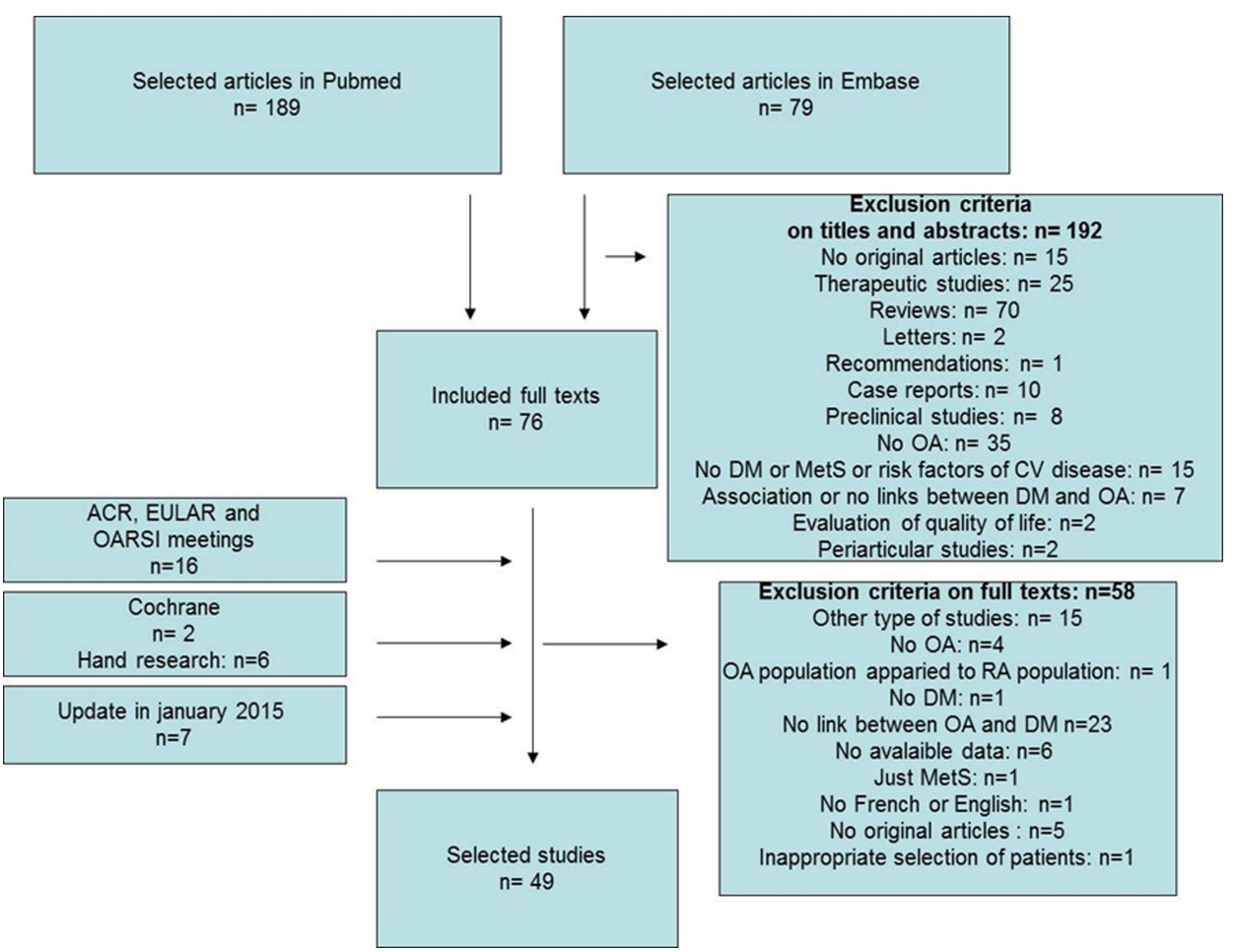

hyperglycaemia was one of the items and involved 5.1$58.6 \%$ of patients. ${ }^{7} 2034364248$

\section{Prevalence of $\mathrm{OA}$ among patients with DM and DM among patients with $O A$}

For 5788 patients with DM, the mean OA prevalence was $29.5 \pm 1.2 \%$ (mean age $=61.01$ years). This prevalence was calculated by using the 5 and 12 studies of patients with $\mathrm{DM}$ and the general population, respectively, with available data on the number of patients with OA in the DM population (see online supplementary table S2). In this population, the prevalence of OA calculated with available data for each localisation was $17.2 \pm 2.0 \%$ for the knee, $^{10} 192034424812.3 \pm 1.3 \%$ for the hip ${ }^{31} 48$ and 38.4 $\pm 6.8 \%$ for the hand. ${ }^{3650}$

For 645089 patients with OA, the DM prevalence was $14.4 \pm 0.1 \%$. It was calculated by using the 19 and 12 studies of patients with OA and the general population, respectively, with available data on the number of patients with DM in the OA population (see online supplementary table S2). Three studies involving patients with OA were not included because they assessed semiquantitative or continuous variables, the Kellgren-Lawrence (KL) score and glycaemia but not OA or DM diagnosis. ${ }^{566063}$

\section{Associations between $\mathrm{OA}$ and DM}

In total, 34 studies assessed the association of $\mathrm{OA}$ and $\mathrm{DM}$ and/or glycaemia or HbAlc proportion; 21 showed a significant association in their conclusions or at least reported $\mathrm{OR}>1$ in the text, ${ }^{7} 10202528293941444650-52$

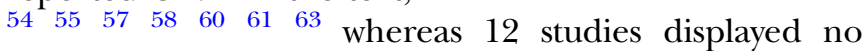
association. $^{161727313438424849}$ 
Table 1 Description of the 49 studies selected for analysis

\begin{tabular}{|c|c|c|c|c|c|c|c|c|c|}
\hline \multirow{2}{*}{$\begin{array}{l}\text { Type of study/ } \\
\text { population }\end{array}$} & \multicolumn{3}{|l|}{ OA } & \multicolumn{3}{|l|}{ Diabetes mellitus } & \multicolumn{3}{|l|}{ General population } \\
\hline & Author & Year & Sample size & Author & Year & Sample size & Author & Year & Sample size \\
\hline \multirow[t]{15}{*}{ Cross-sectional } & Stürmer et al ${ }^{16}$ & 2001 & 809 & Ray et al ${ }^{19}$ & 2011 & 100 & Inoue et $a^{20}$ & 2011 & 795 \\
\hline & Lanas et $a^{P^{1}}$ & 2010 & 3293 & Sarkar et $a^{22}$ & 2008 & 80 & Puenpatom and Victor ${ }^{7}$ & 2009 & 7714 \\
\hline & Reeuwijk et $a^{P^{3}}$ & 2010 & 288 & Miksch et $a^{P^{4}}$ & 2009 & 1399 & Dahaghin et $a^{25}$ & 2007 & 3585 \\
\hline & Adams et $a^{26}$ & 2013 & 39031 & & & & Martin et $a^{P^{7}}$ & 1997 & 739 \\
\hline & Shirinsky and Shirinsky ${ }^{\star 28}$ & 2013 & 5674 & & & & Hart et $a^{29}$ & 1995 & 979 \\
\hline & Cimmino et $a^{\beta 0}$ & 2005 & 2393 & & & & Typpo $^{31}$ & 1985 & 518 \\
\hline & Magnusson et $a^{\beta 2}$ & 2014 & 530 & & & & Schett et $\left.a\right|^{10}$ & 2009 & 927 \\
\hline & Conaghan et $a{ }^{\beta 3}$ & 2014 & 1187 & & & & Navarro et $a l^{\star 34}$ & 2012 & 438 \\
\hline & Zullig et $a /^{35}$ & 2014 & 300 & & & & Orellana et $a{ }^{\star 36}$ & 2012 & 324 \\
\hline & Bija et $a \beta^{37}$ & 2014 & 148 & & & & Anderson and Felson ${ }^{38}$ & 1988 & 5193 \\
\hline & & & & & & & Silveri et $a{ }^{\beta 9}$ & 1994 & 48 \\
\hline & & & & & & & Perruccio et $a{ }^{* 40}$ & 2013 & 983 \\
\hline & & & & & & & Yoshimura et $a \beta$ & 2011 & 1690 \\
\hline & & & & & & & Wang et $a f^{41}$ & 2013 & 1877 \\
\hline & & & & & & & Shin $^{42}$ & 2014 & 2363 \\
\hline \multirow[t]{9}{*}{ Cohort } & Jamsen et $a{ }^{{ }^{3}}$ & 2012 & 96754 & & & & Davies-Tuck et $a{ }^{44}$ & 2012 & 179 \\
\hline & Baker et a ${ }^{\star 45}$ & 2013 & 62 & & & & Siviero et $a l^{46}$ & 2009 & 1867 \\
\hline & Peniston et $a{ }^{47}$ & 2012 & 947 & & & & Engstrom et $a f^{48}$ & 2009 & 5194 \\
\hline & & & & & & & Frey et $a l^{17}$ & 1996 & 1514 \\
\hline & & & & & & & Bagge et $a{ }^{49}$ & 1991 & 340 \\
\hline & & & & & & & $\left(\right.$ Schett $\left.\dagger^{10}\right)$ & 2012 & \\
\hline & & & & & & & Haugen et a/ ${ }^{50}$ & 2013 & 1348 \\
\hline & & & & & & & Sowers et $a^{F^{1}}$ & 2009 & 664 \\
\hline & & & & & & & Visser et $a^{p^{2} 53}$ & 2013 & 4980 \\
\hline \multirow[t]{8}{*}{ Case-control§ } & Philbin et $a{ }^{54}$ & 1996 & 69 & Ladjimi et $a^{55}$ & 1985 & 68 & & & \\
\hline & Denko et $a^{56}$ & 1994 & 135 & Nieves-Plaza et $a^{57}$ & 2013 & 226 & & & \\
\hline & Cimmino et $a^{58}$ & 1990 & 1226 & & & & & & \\
\hline & Lindberg and Nilsson ${ }^{59}$ & 1985 & 558 & & & & & & \\
\hline & Dequeker et $a^{60}$ & 1982 & 53 & & & & & & \\
\hline & Rahman et $a^{61}$ & 2013 & 150267 & & & & & & \\
\hline & Wang et $a^{62 \star}$ & 2013 & 856168 & & & & & & \\
\hline & Horn et $a^{\rho^{3}}$ & 1992 & 76 & & & & & & \\
\hline
\end{tabular}


Table 2 Characteristics of the 49 included studies

\begin{tabular}{|c|c|c|c|c|c|}
\hline Author & Name of study & Diabetes definition & OA definition & $\begin{array}{l}\text { STROBE study } \\
\text { quality (\%) }\end{array}$ & Outcome \\
\hline$\overline{\text { Stürmer et } a l^{16}}$ & Ulm OA & - & Arthroplasty or $\mathrm{KL} \geq 2$ & 57 & NP DM/OA \\
\hline Lanas et $a^{R^{1}}$ & LOGICA & - & - & 63 & NP DM/OA \\
\hline Reeuwijk et $a^{f^{3}}$ & _ & - & ACR & 77 & NP DM/OA \\
\hline Adams et $a^{26}$ & - & $\overline{\mathrm{H}} \mathrm{bA} 1 \mathrm{c} \geq 6.5 \%$ or codes & - & 88 & NP DM/OA \\
\hline $\begin{array}{l}\text { Shirinsky and } \\
\text { Shirinsky }^{28 *}\end{array}$ & OAl & Codes & - & NA & NP DM/OA \\
\hline Jamsen et $a f^{43}$ & PERFECT & Codes or drugs prescription register & Codes & 67 & NP DM/OA \\
\hline Baker et al ${ }^{45 *}$ & - & - & - & NA & NP DM/OA \\
\hline Peniston et $a l^{47}$ & - & - & $\overline{\mathrm{K} L} \geq 3, \mathrm{ACR}$ & 58 & NP DM/OA \\
\hline Philbin $^{54}$ & - & $\begin{array}{l}\text { FBG }>110 \mathrm{mg} / \mathrm{dL} \text { on } 2 \text { samples taken at least } 24 \mathrm{~h} \\
\text { apart }\end{array}$ & $\begin{array}{l}\text { Questionnaire, } \\
\text { radiological Danielson } \\
\text { scale }\end{array}$ & 73 & NP2 \\
\hline Denko et $a{ }^{56}$ & _- & & Pain and $\mathrm{rx}$ & 42 & Glyc in the $\mathrm{OA}$ population \\
\hline Cimmino et $a^{58}$ & - & $\begin{array}{l}\text { FBG } \geq 140 \mathrm{mg} / \mathrm{dL} \text { (National Diabetes data group of the } \\
\text { US National Institutes of Health (USA)+ WHO) }\end{array}$ & $\mathrm{KL} \geq 2$ and pain & 52 & $\begin{array}{l}\text { NP2 and glyc in the OA and control } \\
\text { populations }\end{array}$ \\
\hline $\begin{array}{l}\text { Lindberg and } \\
\text { Nilssson }\end{array}$ & - & - & $\mathrm{Rx}$ before arthroplasty & 36 & NP2 \\
\hline Dequeker et $a^{{ }_{0} 0}$ & & & & 33 & Glyc in the $\mathrm{OA}$ and control populations \\
\hline Rahman et $a^{{ }^{11}}$ & $\overline{\mathrm{CCHS}}$ & Questionnaire & Questionnaire & 73 & NP2 \\
\hline Wang et $a^{2 *}$ & - & - & Reported & NA & NP2 \\
\hline Horn et $a \rho^{\rho^{3}}$ & - & - & $\mathrm{KL}$ & 55 & $\begin{array}{l}\mathrm{KL} \text { in the } \mathrm{DM} \text { and non-DM, OA populations } \\
\text { (semiquantitative scale) }\end{array}$ \\
\hline Ray et al ${ }^{19}$ & - & $\begin{array}{l}\text { WHO criteria: } \mathrm{FBG}>7 \mathrm{mmol} / \mathrm{L} \text { or } 2 \mathrm{~h} \text { PPFG glucose } \\
>11.1 \mathrm{mmol} / \mathrm{L} \text { after oral glucose test or diabetes } \\
\text { symptoms and } \mathrm{FPG}>11.1 \mathrm{mmol} / \mathrm{L}\end{array}$ & Clinical, $\mathrm{Rx}, \mathrm{ACR}$ & 50 & NP OA/DM \\
\hline Sarkar et $a P^{2}$ & 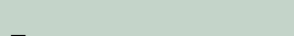 & FBG, PPBG and $\mathrm{HbA} 1 \mathrm{c}$ & Clinical and $R x$ & 45 & NP OA/DM \\
\hline Miksch et $a f^{24}$ & $\bar{E} L S I D$ & Questionnaire & Questionnaire & 75 & NP OA/DM \\
\hline Ladjimi et $a^{55}$ & - & Glyc and $\mathrm{HbA} 1 \mathrm{c}$ & Clinical and $\mathrm{Rx}$ & 45 & NP2 \\
\hline $\begin{array}{l}\text { Nieves-Plaza } \\
\text { et } a^{p^{7}}\end{array}$ & - & $\begin{array}{l}\text { National Diabetes Data Group Classification: } \\
\text { symptoms+FBG }>200 \mathrm{mg} / \mathrm{dL} \text { or FBG }>126 \mathrm{mg} / \mathrm{dL} \text { or } \\
2 \mathrm{~h} \text { PPBG }>200 \mathrm{mg} / \mathrm{dL} \text { after an oral glucose test }\end{array}$ & ACR & 82 & NP2 \\
\hline Inoue et $a P^{0}$ & $\begin{array}{l}\text { Iwaki Health Promotion } \\
\text { Project }\end{array}$ & $\mathrm{HbA} 1 \mathrm{c}>5.8 \%$ & $\mathrm{KL} \geq 2$ & 69 & $\begin{array}{l}\mathrm{NP} 2 \text { and } \mathrm{HbA} 1 \mathrm{c} \text { in the } \mathrm{OA} \text { and non-OA } \\
\text { populations }\end{array}$ \\
\hline $\begin{array}{l}\text { Puenpatom and } \\
\text { Victor }^{7}\end{array}$ & NHANES III & $\begin{array}{l}\mathrm{FBG} \geq 110 \mathrm{mg} / \mathrm{dL} \text {, codes, history of diabetes or drugs } \\
\text { for diabetes }\end{array}$ & $\begin{array}{l}\text { Codes, } \mathrm{Rx} \text { or history of } \\
\text { OA by physician }\end{array}$ & 69 & NP2 \\
\hline Dahaghin et $a^{25}$ & Rotterdam & FBG or PPBG $\geq 11.0 \mathrm{mmol} / \mathrm{L}$ or drugs for diabetes & $\begin{array}{l}\mathrm{KL} \geq 2 \text { (hand } \mathrm{Rx} \text { ) and } \\
\text { clinical (ACR) }\end{array}$ & 78 & NP2 \\
\hline Martin et $a^{R^{7}}$ & BLSA & $\begin{array}{l}\mathrm{FBG} \geq 140 \mathrm{mg} / \mathrm{dL} \text { or } 2 \mathrm{~h} \text { PPBG } \geq 200 \mathrm{mg} / \mathrm{dL} \text { or drugs } \\
\text { for diabetes }\end{array}$ & $\mathrm{KL} \geq 2$ & 66 & $\begin{array}{l}\text { FBG and PPBG in the OA and non-OA } \\
\text { populations }\end{array}$ \\
\hline Hart et a ${ }^{99}$ & - & History of diabetes or $\mathrm{FBG} \geq 12.8 \mathrm{mmol} / \mathrm{L}$ & $\mathrm{KL} \geq 2$ (knee $\mathrm{Rx})$ & 78 & $\begin{array}{l}\text { Glyc in the } \mathrm{OA} \text { and/or DM population } \\
\text { (semiquantitative scale) }\end{array}$ \\
\hline Typpo ${ }^{31}$ & & Reported & $\mathrm{Rx}$ & 44 & NP2 \\
\hline Schett et $a l^{10} \dagger$ & Bruneck study & $\begin{array}{l}\text { FBG } \geq 7 \mathrm{mmol} / \mathrm{L} \text { or } 126 \mathrm{mg} / \mathrm{dL} \text {, or drugs for diabetes or } \\
\mathrm{HbA} 1 \mathrm{c} \geq 6.5 \% \text { or PPBG } \geq 11.1 \mathrm{mmol} / \mathrm{L} \text { or } 200 \mathrm{mg} / \mathrm{dL}\end{array}$ & $\begin{array}{l}\text { Arthroplasty for hip or } \\
\text { knee OA }\end{array}$ & 81 & $\begin{array}{l}\text { NP2 and Glyc in the OA and non-OA } \\
\text { populations }\end{array}$ \\
\hline
\end{tabular}




\begin{tabular}{|c|c|c|c|c|c|}
\hline Author & Name of study & Diabetes definition & OA definition & $\begin{array}{l}\text { STROBE study } \\
\text { quality (\%) }\end{array}$ & Outcome \\
\hline Navarro et $a{ }^{\beta 4 *}$ & - & Database of public health service & - & NA & NP2 \\
\hline Orellana et $a^{\beta 6 *}$ & - & Database of public health service & - & NA & NP2 \\
\hline $\begin{array}{l}\text { Anderson and } \\
\text { Felson } \\
38\end{array}$ & HANES I & History of diabetes & $\begin{array}{l}\mathrm{KL} \geq 2(\mathrm{knee} \mathrm{Rx}) \text { and } \\
\text { pain } \geq 1 \text { month }\end{array}$ & 81 & OR of OA in the DM population \\
\hline Silveri et $a \beta^{\beta 9}$ & - & FBG & Clinical and Rx & 56 & NP2 \\
\hline Perruccio et $a /^{40 *}$ & - & Reported & - & NA & NP DM/OA \\
\hline $\begin{array}{l}\text { Yoshimura } \\
\text { et } a^{\beta} \dagger\end{array}$ & ROAD & $\mathrm{HbA} 1 \mathrm{c} \geq 5.5 \%$ or drugs for diabetes & $\mathrm{KL} \geq 2($ knee $R x)$ & 91 & $\mathrm{HbA} 1 \mathrm{c}$ in the $\mathrm{OA}$ and non-OA populations \\
\hline $\begin{array}{l}\text { Davies-Tuck } \\
\text { et } a f^{44}\end{array}$ & MCCS & FBG $\geq 7 \mathrm{mmol} / \mathrm{L}$ or reported (exclusion) & ACR & 73 & $\begin{array}{l}\text { Glyc, cartilage volume and bone marrow } \\
\text { lesions }\end{array}$ \\
\hline Siviero et $a{ }^{46}$ & ILSA & $\mathrm{FBG} \geq 140 \mathrm{mg} / \mathrm{dL}$ or drugs for diabetes & History and clinical & 55 & NP2 \\
\hline Engstrom et $a f^{48}$ & MDC & $\mathrm{FBG} \geq 5.6 \mathrm{mmol} / \mathrm{L}$ & $\begin{array}{l}\text { Codes: arthroplasty for } \\
\text { hip or knee OA }\end{array}$ & 79 & NP2 (data for knee and data for hip) \\
\hline Frey et al ${ }^{17}$ & Rancho Bernardo Cohort & $\begin{array}{l}\mathrm{FBG} \geq 140 \mathrm{mmol} / \mathrm{L} \text { twofold or } \mathrm{PPBG} \geq 200 \mathrm{mg} / \mathrm{dL} \\
\text { after an oral glucose test }\end{array}$ & $\begin{array}{l}\text { Clinical (nurse } \\
\text { examination) or history of } \\
\text { OA }\end{array}$ & 70 & NP2 (data for men and data for women) \\
\hline Bagge et $a l^{49}$ & - & $\mathrm{FBG} \geq 8.3 \mathrm{mmol} / \mathrm{L}$ or drugs for diabetes & $\mathrm{KL} \geq 2$ (knee and hand) & 67 & $\begin{array}{l}\text { NP OA/DM (but NP DM at baseline and NP } \\
\text { OA at end point) }\end{array}$ \\
\hline Haugen et $a^{50}$ & Framingham & $\mathrm{FBG} \geq 126 \mathrm{mg} / \mathrm{dL}$ or $\mathrm{PPBG} \geq 200 \mathrm{mg} / \mathrm{dL}$ & Clinical and $R x(K L \geq 2)$ & 84 & $\begin{array}{l}\text { NP2 (data for radiological OA and } \\
\text { symptomatic OA, exclusive groups) }\end{array}$ \\
\hline Sowers et $a^{\Gamma^{1}}$ & MBHMS & $\begin{array}{l}\text { History of diabetes or drugs for diabetes or FBG } \\
>126 \mathrm{mg} / \mathrm{dL}\end{array}$ & $\mathrm{KL} \geq 2$ (knee Rx) & 70 & Glyc for the $\mathrm{OA}$ and non-OA population \\
\hline Visser et $a^{\Gamma^{2} 53 *}$ & NEO & FBG $\geq 5.6 \mathrm{mmol} /$ Lor drugs for diabetes & ACR & 84 & OR of Glyc and $\mathrm{HbA} 1 \mathrm{c}$ in the OA population \\
\hline Wang et $a f^{41}$ & Inner Mongolia OA Study & Questionnaire & Clinical and $R x(K L \geq 2)$ & 69 & $\begin{array}{l}\text { Number of patients with } O A \text { in the general } \\
\text { population but no data on the number of } \\
\text { patients with diabetes }\end{array}$ \\
\hline $\operatorname{Shin}^{42}$ & KNHANES V-1 & $\mathrm{FBG} \geq 100 \mathrm{mg} / \mathrm{dL}$ or drugs for diabetes & $R x(K L \geq 2)$ & 74 & NP2 \\
\hline Cimmino et $a{ }^{\beta 0}$ & AMICA & Questionnaire & ACR & 53 & NP DM/OA \\
\hline $\begin{array}{l}\text { Magnusson } \\
\text { et } a^{\beta 2}\end{array}$ & MUST & Questionnaire & $\begin{array}{l}\mathrm{ACR} \text { and hand } \mathrm{Rx}(\geq 1 \\
\text { joint with } \mathrm{KL} \geq 2)\end{array}$ & 74 & NP DM/OA \\
\hline Conaghan et $a \beta^{33}$ & SORT & Questionnaire & Clinical & 72 & NP DM/OA \\
\hline Zullig et $a \beta^{\beta 5}$ & $\begin{array}{l}\text { Patient and provider } \\
\text { interventions for managing } \\
\text { OA in primary care }\end{array}$ & Reported & ACR or $\mathrm{Rx}$ & 66 & NP DM/OA \\
\hline Bija et $a \beta^{37}$ & - & Reported & $\begin{array}{l}\text { ACR or } R x \text { with } K L \text { but } \\
\text { no cut-off (including } \\
K L=1 \text { ) }\end{array}$ & 72 & NP DM/OA \\
\hline
\end{tabular}

*Data only from abstract of congress.

†One cross-sectional study and one prospective study (the cross-sectional study was selected for analysis).

ACR, American College of Rheumatology criteria; CCHS, Canadian Community Health Survey; DM, diabetes mellitus; ELSID, Evaluation of a Large Scale Implementation of Disease

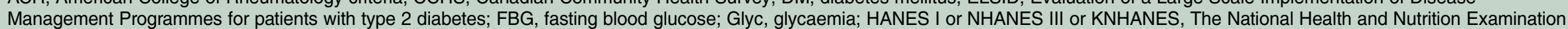
Survey I or III or Korean NHANES; HbA1c, glycosylated haemoglobin; ILSA, The Italian Longitudinal Study on Aging; KL, Kellgren and Lawrence scale; MBHMS, Michigan Bone Health \& Metabolism Study; MCCS, The Melbourne Collaborative Cohort Study; MDC, the Malmo Diet and Cancer Study; MUST, Musculoskeletal pain in Ullensaker study; NEO, The Netherlands Epidemiology of Obesity study; NA, not available; NP DM/OA, number of patients with DM in the OA population only; NP OA/DM, number of patients with OA in the DM population only; NP2, number of patients with OA and/or DM in the disease group and control group $\rightarrow$ need to calculate prevalence and OR; OAl, Osteoarthritis Initiative; OA, osteoarthritis;

PPBG, postprandial blood glucose; ROAD, Research on Osteoarthritis Against Disability; Rx, radiography; SORT, Study of osteoarthritis Real World Therapies; STROBE, Strengthening the Reporting of Observational Studies in Epidemiology (NA if the data were issued only from congress). 
Figure 2 Forest plot for osteoarthritis among patients with and without diabetes mellitus.

\begin{tabular}{|c|c|c|c|c|c|c|c|c|c|}
\hline \multirow[b]{2}{*}{ Study or Subgroup } & \multicolumn{2}{|c|}{ Diabetes } & \multicolumn{2}{|c|}{ Non diabetes } & \multirow[b]{2}{*}{ Weight } & \multirow{2}{*}{$\begin{array}{c}\text { Odds Ratio } \\
\mathrm{M}-\mathrm{H}, \text { Random, } 95 \% \mathrm{Cl}\end{array}$} & \multirow{2}{*}{\multicolumn{2}{|c|}{$\begin{array}{c}\text { Odds Ratio } \\
\mathrm{M}-\mathrm{H}, \text { Random, } 95 \% \mathrm{Cl}\end{array}$}} & \\
\hline & Events & Total & Events & Total & & & & & \\
\hline Ladjimi & 20 & 34 & 10 & 34 & $4.0 \%$ & $3.43[1.25,9.37]$ & & & \\
\hline Schett & 11 & 65 & 49 & 847 & $5.2 \%$ & $3.32[1.63,6.75]$ & & & \\
\hline Frey (Men) & 10 & 69 & 113 & 396 & $5.2 \%$ & $0.42[0.21,0.86]$ & & & \\
\hline Inoue & 13 & 35 & 238 & 748 & $5.2 \%$ & $1.27[0.63,2.56]$ & & & \\
\hline Orellana & 13 & 59 & 57 & 265 & $5.3 \%$ & $1.03[0.52,2.04]$ & & & \\
\hline Haugen (Symptomatic OA) & 14 & 52 & 172 & 756 & $5.5 \%$ & $1.25[0.66,2.36]$ & & & \\
\hline Nieves-Diaza & 49 & 100 & 27 & 102 & $5.7 \%$ & $2.67[1.48,4.81]$ & & & \\
\hline Typpo & 25 & 55 & 229 & 463 & $5.8 \%$ & $0.85[0.49,1.49]$ & & & \\
\hline Engstrom (Hip) & 16 & 833 & 104 & 4331 & $5.9 \%$ & $0.80[0.47,1.35]$ & & & \\
\hline Frey (Women) & 32 & 73 & 210 & 520 & $6.1 \%$ & $1.15[0.70,1.89]$ & & & \\
\hline Navarro & 35 & 81 & 149 & 357 & $6.1 \%$ & $1.06[0.65,1.73]$ & & & \\
\hline Engstrom (Knee) & 26 & 834 & 63 & 4337 & $6.2 \%$ & $2.18[1.37,3.47]$ & & & \\
\hline Haugen (Radiographic OA) & 49 & 87 & 491 & 1075 & $6.3 \%$ & $1.53[0.99,2.38]$ & & & \\
\hline Siviero (shoulder) & 32 & 224 & 145 & 1643 & $6.4 \%$ & $1.72[1.14,2.60]$ & & & \\
\hline Dahaghin & 86 & 265 & 900 & 3320 & $6.9 \%$ & $1.29[0.99,1.69]$ & & & \\
\hline Shin & 134 & 299 & 785 & 2064 & $7.0 \%$ & $1.32[1.04,1.69]$ & & & \\
\hline Puenpatom & 299 & 1054 & 676 & 6660 & $7.2 \%$ & $3.51[3.00,4.10]$ & & - & - \\
\hline Total $(95 \% \mathrm{Cl})$ & & 4219 & & 27918 & $100.0 \%$ & $1.46[1.08,1.96]$ & & & \\
\hline Total events & 864 & & 4418 & & & & & & \\
\hline $\begin{array}{l}\text { Heterogeneity: } \operatorname{Tau}^{2}=0.32 ; \\
\text { Test for overall effect: } Z=2.4\end{array}$ & $\begin{array}{l}\mathrm{i}^{2}=134 \\
(P=0.01\end{array}$ & $81, d f=$ & $16(P<0$ & $.00001)$ & $\left.\right|^{2}=88 \%$ & & $\begin{array}{lll} & 1 & 1 \\
0.1 & 0.2 & 0.5 \\
& \text { Non } & \text { OA }\end{array}$ & $\mathrm{OA}^{2}$ & 510 \\
\hline
\end{tabular}

but 7 identified DM as an independent risk factor of $\mathrm{OA}^{8} 102944465157$ and were of higher quality as illustrated by the mean STROBE scale $(69 \pm 7.4 \%$ vs 76 $\pm 8.5 \%$, respectively). Interestingly, the positive studies were the recent ones: six of seven were published between 2009 and 2013. ${ }^{810} 44465157$ Considering OA localisations: the results were significant for knee OA-only and hand OA-only (OR=1.64 (1.17 to 2.29) with 9170 patients $^{102034424855}$ and OR=1.31(1.07 to 1.61 ) with 5879 patients, ${ }^{25} 3650$ respectively) but not for hip $(\mathrm{OR}=0.82$ (0.56 to 1.21$)$, with 5682 patients). ${ }^{31} 48$

Risk of DM in OA: meta-analysis and sensitivity analyses For risk of DM in an OA versus non-OA population, among 1040175 patients, the overall OR was 1.41 (1.21 to 1.65 ), assessed by a random-effects model because of $\mathrm{I}^{2}=95 \%$ (figure 3 ).

We performed four sensitivity analyses to strengthen the results. First, with the heterogeneity explained by two studies with aberrant results, we removed these two studies. ${ }^{54} 59$ The OR remained similar: 1.42 (1.22 to 1.66 ), $\mathrm{I}^{2}=96 \%$. Second, we focused on severe OA (ie, the
Figure 3 Forest Plot for DM among patients with and without OA (OA, osteoarthritis; DM, diabetes mellitus). even in patients at increased association remained even in patients at increased ris of OA because of their age. ${ }^{25} 34364246$

Among the 12 studies with OR adjusted on BMI, 5 showed no association between DM and OA, ${ }^{16} 25274849$ 
3 studies with surgery as an OA outcome corresponding to 11805 patients); the OR was not significant: 1.32 (0.52 to 3.36) but with high heterogeneity $\left(\mathrm{I}^{2}=85 \%\right) .{ }^{10} 4859$ Third, we removed the studies that did not use internationally recognised diagnosis criteria for OA such as ACR criteria or the KL score for OA definition; the OR was 1.32 (1.13 to 1.53) without any heterogeneity $\left(\mathrm{I}^{2}=0 \%\right)$ with five studies and 9947 patients. ${ }^{20} 25425058$ Fourth, we considered OA localisations: for data involving knee OA only or hip OA only, the results were significant for the knee $(\mathrm{OR}=1.51$ (1.09 to 2.09) with 5 studies and 9102 patients) but not for the hip ( $\mathrm{OR}=0.71$ ( 0.49 to 1.04 ) with 3 studies and 6240 patients). ${ }^{10} 203134424859$ We also found a significant association for non-weight-bearing hand $\mathrm{OA}(\mathrm{OR}=1.31$ (1.07 to 1.61$)$ ). There was no study that included only generalised OA.

\section{DISCUSSION}

$\mathrm{OA}$ is a heterogeneous disorder that can be separated in an age-related, metabolic and post-traumatic OA, representing thus the three main phenotypes of the disease. Metabolic OA is wider than obesity-related OA since MetS and $\mathrm{OA}$ are epidemiologically linked. ${ }^{2}{ }^{7}$ However, the association between each component of the MetS and OA needs to be further addressed. Likewise, we aimed to assess the overall link between OA and DM. We performed a systematic review of the literature and meta-analysis of data from 49 studies involving a large sample of participants $(n=1$ 192518). The prevalence of OA among patients with DM was $29.5 \pm 1.2 \%$ and that of DM among patients with $\mathrm{OA}$ was $14.4 \pm 0.1 \%$. Moreover, OA and DM were significantly associated: the overall risk of $\mathrm{OA}$ in the DM population was 1.46 (1.08 to 1.96) and that of DM in the OA population was 1.41 (1.21 to 1.65 ).

In the DM population, the risk of OA was significant with overall data. All studies had approximately the same weight in the analysis. Such a result was confirmed in patients older than 50 years: DM seems to be associated with $\mathrm{OA}$, even when age may have a significant impact on OA, which suggests that the link with DM does not depend on age.

In the OA population, the risk of DM was also significant $(\mathrm{OR}=1.41$ (1.21 to 1.65)). Data from two studies had an important weight on this finding: DM prevalence in the OA group was $9.7 \%$ in the study of Rahman et $a l^{61}$ and $9.8 \%$ in the work of Wang et at ${ }^{62}$ coming from a congress abstract, and the definitive publication for this abstract will be critical to confirm these results. It can influence the final outcome, but the Rahman et $a l^{61}$ study was of good quality. The association of OA and DM was not significant when we considered only studies of severe OA (ie, time to joint replacement), probably because of the small number of patients. ${ }^{10} 4859$ The role of DM in progression of $\mathrm{OA}$ is controversial since Yoshimura et $a l^{64}$ have found that DM defined as HbAlc fraction $\geq 5.5 \%$ was not independently associated with OA progression, whereas in a recent study type 2 DM was a significant predictor of joint space narrowing in males with symptomatic knee OA. ${ }^{65}$

In addition, recruitment bias at the time of joint replacement may explain the findings because the presence of comorbidities such as DM may restrict the indication for surgery in terms of a potential increase in subsequent perioperative adverse events. We found an especially significant association between DM and OA with the studies including hand OA only, which highlights the metabolic and systemic nature of hand OA, highlighted recently in the NEO cohort. ${ }^{53} 66$ Moreover, the impact of DM on symptoms or on structural lesions might be different. Schett $e t a l^{67}$ have shown that symptoms of $\mathrm{OA}$ assessed using the Knee injury and Osteoarthritis Outcome Score (KOOS) and the Western Ontario and McMaster Universities Arthritis Index (WOMAC) were more severe and ultrasound synovitis and effusion of knees more frequent in participants with type $2 \mathrm{DM}$ than those without DM. This inflammatory aspect in imaging corroborates with the higher release of inflammatory mediators in OA cartilage explants from patients with DM than those from patients without $\mathrm{DM}^{68}$ The well control of DM by antidiabetic therapies could also influence the prevalence of OA: HbA1c fraction, that reflects the three last months of DM control, was significantly higher in women knee OA for Yoshimura et $a l^{8}{ }^{64}$ and for Inoue et al..$^{20}$ However, we had no data about the history of the DM control during the previous years during which OA developed and progressed. Moreover, data about antidiabetic drugs were used only to identify patients with DM, but not as a factor able to influence OA occurrence or progression. The assessment of the radiographic patterns of DM-related OA (ie, erosive OA, diffuse idiopathic skeletal hyperostosis) was not possible due to a lack of data. The prevalence of $\mathrm{OA}$ in patients with $\mathrm{DM}$ was 14.4 $\pm 0.1 \%$. We measured prevalence of DM among patients with OA, emphasising the link between both diseases. This prevalence could be compared with the prevalence of $\mathrm{OA}$ in the general population, but it depends on the reference population: $32 \%$ of $\mathrm{OA}$ in Iwaki Health Promotion Project (Japan) and $13 \%$ of OA in NHANES III (USA). ${ }^{7}{ }^{20}$ We lack basic data on the impact of OA on DM, but this remains to be investigated because of the possible systemic effects of OA. ${ }^{69}$

Our meta-analysis has some limitations. The heterogeneity was high in the first analyses, probably because of population characteristics (various OA localisations or definitions, various DM definitions, no stratification on DM severity or treatment) or various types and qualities of studies. However, we performed several sensitivity analyses, which allowed a decrease in the heterogeneity level, in particular in subgroups with a well-recognised definition of inclusion criteria of OA. To further decrease heterogeneity, we eliminated some studies: those that were of low quality or with a diagnosis of OA not based on ACR criteria or KL grading..$^{39} 41 \quad 5460$ 
However, the heterogeneity and results did not greatly change because of the low weight of these studies in the meta-analysis. Another limitation is the impact of confounding factors, especially age and obesity. However, despite a significant impact of increasing age on OA, the association remained positive when we retained studies including patients older than 50 years. Moreover, we identified seven studies showing an association even after adjustment on BMI in their multivariate logistic regression. The mean score of quality was better and most were recent (results published after 2009). Confounding factors such as joint injury, physical activity, smoking, hypertension, dyslipidaemia might have affected our findings, but these factors were taken into account in each included study. ${ }^{8}{ }^{10}$ In patients with DM, neuropathy may also affect OA development, but we did not find this information in the selected studies.

We have shown an association of DM and OA, but causality is not yet clearly demonstrated. Hyperglycaemia could promote joint inflammation and cartilage degradation through oxidative stress and inflammatory mediators induction as well as through AGEs. ${ }^{12}$ Beyond a chronic excess of glucose, type $2 \mathrm{DM}$ is characterised by increased insulin resistance that may be involved in osteophyte development and subchondral bone sclerosis. ${ }^{9} 7071$ We thus need additional specific prospective studies for that purpose.

In summary, this is the first meta-analysis showing an association of $\mathrm{OA}$ and DM, giving some additional clues about the delineation of the metabolic OA phenotype. Large prospective studies are needed to address whether $\mathrm{DM}$ is an independent risk factor of OA development or severity. If this is the case, new preventive and/or curative modalities based on glycaemia control could be tested in OA.

Acknowledgements The authors thank Laura SMALES (BioMed Editing, Toronto, Canada) for editing the manuscript. KL, FB and JS are supported by The Foundation Arthritis Network Program (ROAD project).

Contributors KL, JS and FB were involved in conception and design. $\mathrm{KL}$ was involved in acquisition of data and statistical analysis. KL, CV, JS and FB were involved in analyses and interpretation of data, drafting of the manuscript, revision of the manuscript and final approval. KL, JS and FB had full access to all of the data in the study and take responsibility for the integrity of the data and the accuracy of the data analysis.

Competing interests None.

Provenance and peer review Not commissioned; externally peer reviewed.

Data sharing statement No additional data are available.

Open Access This is an Open Access article distributed in accordance with the Creative Commons Attribution Non Commercial (CC BY-NC 4.0) license, which permits others to distribute, remix, adapt, build upon this work noncommercially, and license their derivative works on different terms, provided the original work is properly cited and the use is non-commercial. See: http:// creativecommons.org/licenses/by-nc/4.0/

\section{REFERENCES}

1. Yusuf E, Nelissen RG, loan-Facsinay A, et al. Association between weight or body mass index and hand osteoarthritis: a systematic review. Ann Rheum Dis 2010;69:761-5.
2. Bijlsma JW, Berenbaum F, Lafeber FP. Osteoarthritis: an update with relevance for clinical practice. Lancet 2011;377:2115-26.

3. Abella V, Scotece M, Conde J, et al. Adipokines, metabolic syndrome and rheumatic diseases. J Immunol Res 2014;2014:343746.

4. Chauffier K, Laiguillon MC, Bougault $\mathrm{C}$, et al. Induction of the chemokine IL-8/Kc by the articular cartilage: possible influence on osteoarthritis. Joint Bone Spine 2012;79:604-9.

5. Laiguillon $\mathrm{MC}$, Houard $\mathrm{X}$, Bougault $\mathrm{C}$, et al. Expression and function of visfatin (Nampt), an adipokine-enzyme involved in inflammatory pathways of osteoarthritis. Arthritis Res Ther 2014;16:R38.

6. Alberti KG, Zimmet P, Shaw J. The metabolic syndrome-a new worldwide definition. Lancet 2005;366:1059-62.

7. Puenpatom RA, Victor TW. Increased prevalence of metabolic syndrome in individuals with osteoarthritis: an analysis of NHANES III data. Postgrad Med 2009;121:9-20.

8. Yoshimura N, Muraki S, Oka $\mathrm{H}$, et al. Association of knee osteoarthritis with the accumulation of metabolic risk factors such as overweight, hypertension, dyslipidemia, and impaired glucose tolerance in Japanese men and women: the ROAD study. $J$ Rheumatol 2011;38:921-30.

9. Karvonen-Gutierrez CA, Sowers MR, Heeringa SG. Sex dimorphism in the association of cardiometabolic characteristics and osteophytes-defined radiographic knee osteoarthritis among obese and non-obese adults: NHANES III. Osteoarthritis Cartilage 2012;20:614-21.

10. Schett G, Kiechl S, Bonora E, et al. Vascular cell adhesion molecule 1 as a predictor of severe osteoarthritis of the hip and knee joints. Arthritis Rheum 2009;60:2381-9.

11. Waine $\mathrm{H}$, Nevinny D, Rosenthal J, et al. Association of osteoarthritis and diabetes mellitus. Tufts Folia Med 1961;7:13-19.

12. Berenbaum F. Diabetes-induced osteoarthritis: from a new paradigm to a new phenotype. Ann Rheum Dis 2011;70:1354-6.

13. Mobasheri A. Glucose: an energy currency and structural precursor in articular cartilage and bone with emerging roles as an extracellular signaling molecule and metabolic regulator. Front Endocrinol (Lausanne) 2012;3:153.

14. Verzijl N, Bank RA, TeKoppele JM, et al. AGEing and osteoarthritis: a different perspective. Curr Opin Rheumatol 2003;15:616-22.

15. Atayde SA, Yoshinari NH, Nascimento DP, et al. Experimental diabetes modulates collagen remodelling of joints in rats. Histol Histopathol 2012;27:1471-9.

16. Sturmer $\mathrm{T}$, Brenner $\mathrm{H}$, Brenner RE, et al. Non-insulin dependent diabetes mellitus (NIDDM) and patterns of osteoarthritis. The UIm osteoarthritis study. Scand J Rheumatol 2001;30:169-71

17. Frey MI, Barrett-Connor E, Sledge PA, et al. The effect of noninsulin dependent diabetes mellitus on the prevalence of clinical osteoarthritis. A population based study. J Rheumatol 1996:23:716-22.

18. von Elm E, Altman DG, Egger M, et al. [The Strengthening the Reporting of Observational Studies in Epidemiology (STROBE) statement: guidelines for reporting observational studies]. Rev Esp Salud Publica 2008;82:251-9.

19. Ray S, Datta AK, Sinhamahapatra $P$, et al. Prevalence of rheumatic conditions in patients with diabetes mellitus in a tertiary care hospital. J Indian Med Assoc 2011;109:74-8.

20. Inoue R, Ishibashi $\mathrm{Y}$, Tsuda $\mathrm{E}$, et al. Medical problems and risk factors of metabolic syndrome among radiographic knee osteoarthritis patients in the Japanese general population. J Orthop Sci 2011;16:704-9.

21. Lanas A, Tornero J, Zamorano JL. Assessment of gastrointestinal and cardiovascular risk in patients with osteoarthritis who require NSAIDs: the LOGICA study. Ann Rheum Dis 2010;69:1453-8.

22. Sarkar P, Pain S, Sarkar RN, et al. Rheumatological manifestations in diabetes mellitus. J Indian Med Assoc 2008;106:593-4.

23. Reeuwijk KG, de Rooij M, van Dijk GM, et al. Osteoarthritis of the hip or knee: which coexisting disorders are disabling? Clin Rheumatol 2010;29:739-47.

24. Miksch A, Hermann K, Rolz A, et al. Additional impact of concomitant hypertension and osteoarthritis on quality of life among patients with type 2 diabetes in primary care in Germany-a cross sectional survey. Health Qual Life Outcomes 2009;7:19.

25. Dahaghin S, Bierma-Zeinstra SM, Koes BW, et al. Do metabolic factors add to the effect of overweight on hand osteoarthritis? The Rotterdam Study. Ann Rheum Dis 2007;66:916-20.

26. Adams AL, Paxton EW, Wang JQ, et al. Surgical outcomes of total knee replacement according to diabetes status and glycemic control 2001 to 2009. J Bone Joint Surg Am 2013;95:481-7.

27. Martin K, Lethbridge-Cejku M, Muller DC, et al. Metabolic correlates of obesity and radiographic features of knee osteoarthritis: data from the Baltimore Longitudinal Study of Aging. J Rheumatol 1997;24:702-7. 
28. Shirinsky I, Shirinsky V. Diabetes effects on pain and physical function in incidence and progression subcohorts of the osteoarthritis initiative: a 5-year longitudinal data analysis. EULAR Congress; 2013;Abstract OP0026.

29. Hart DJ, Doyle DV, Spector TD. Association between metabolic factors and knee osteoarthritis in women: the Chingford Study. $J$ Rheumatol 1995;22:1118-23.

30. Cimmino MA, Sarzi-Puttini P, Scarpa R, et al. Clinical presentation of osteoarthritis in general practice: determinants of pain in Italian patients in the AMICA study. Semin Arthritis Rheum 2005;35:17-23.

31. Typpo T. Osteoarthritis of the hip. Radiologic findings and etiology. Ann Chir Gynaecol Suppl 1985;201:1-38.

32. Magnusson K, Hagen KB, Osteras N, et al. Diabetes is associated with increased hand pain in erosive hand osteoarthritis-data from a population-based study. Arthritis Care Res (Hoboken) 2015;67:187-95

33. Conaghan PG, Peloso PM, Everett SV, et al. Inadequate pain relief and large functional loss among patients with knee osteoarthritis: evidence from a prospective multinational longitudinal study of osteoarthritis real-world therapies. Rheumatology (Oxford) 2015;54:270-7.

34. Navarro N, Orellana C, Vasquez I, et al. High frequency of cardiovascular disease in patients with knee osteoarthritis in a primary care setting. EULAR Congress; 2012;Abstract SAT0320.

35. Zullig LL, Bosworth HB, Jeffreys AS, et al. The association of comorbid conditions with patient-reported outcomes in Veterans with hip and knee osteoarthritis. Clin Rheumatol 2014. Published Online First.

36. Orellana C, Navarro N, Calvet J, et al. Higher frequency of metabolic syndrome in patients with hand osteoarthritis is more pronounced in obese patients. EULAR Congress; 2012;Abstract FRI0305.

37. Bija MD, Luma HN, Temfack E, et al. Patterns of knee osteoarthritis in a hospital setting in sub-Saharan Africa. Clin Rheumatol 2014. Published Online First.

38. Anderson JJ, Felson DT. Factors associated with osteoarthritis of the knee in the first national Health and Nutrition Examination Survey (HANES I). Evidence for an association with overweight, race, and physical demands of work. Am J Epidemiol 1988;128:179-89.

39. Silveri F, Brecciaroli D, Argentati F, et al. Serum levels of insulin in overweight patients with osteoarthritis of the knee. J Rheumatol 1994;21:1899-902.

40. Perruccio AV, Kandel RA, Davis AM. Cardiovascular disease in osteoarthritis: hip versus knee and the influence of multiple symptomatic joint involvement. ACR Congress; 2013;Abstract 266.

41. Wang Y, Peng R, Ma R. Epidemiological investigation of osteoarthritis in middle-aged Mongolian and senior residents of the inner Mongolia autonomous region. Iran Red Crescent Med $J$ 2013;15:e8303

42. Shin D. Association between metabolic syndrome, radiographic knee osteoarthritis, and intensity of knee pain: results of a national survey $J$ Clin Endocrinol Metab 2014;99:3177-83.

43. Jamsen E, Peltola M, Eskelinen A, et al. Comorbid diseases as predictors of survival of primary total hip and knee replacements: a nationwide register-based study of 96754 operations on patients with primary osteoarthritis. Ann Rheum Dis 2012;72:1975-82.

44. Davies-Tuck ML, Wang Y, Wluka AE, et al. Increased fasting serum glucose concentration is associated with adverse knee structural changes in adults with no knee symptoms and diabetes. Maturitas 2012;72:373-8.

45. Baker C, Aileen L, Lavalley MP, et al. Automated telephone-linked communication: a novel approach to enhance long-term adherence to resistance training exercice among people with knee osteoarthritis. ACR Congress; 2013;Abstract 1818.

46. Siviero $P$, Tonin $P$, Maggi S. Functional limitations of upper limbs in older diabetic individuals. The Italian Longitudinal Study on Aging. Aging Clin Exp Res 2009;21:458-62.

47. Peniston JH, Gold MS, Wieman MS, et al. Long-term tolerability of topical diclofenac sodium $1 \%$ gel for osteoarthritis in seniors and patients with comorbidities. Clin Interv Aging 2012;7:517-23.

48. Engstrom G, Gerhardsson de Verdier M, Rollof J, et al. C-reactive protein, metabolic syndrome and incidence of severe hip and knee osteoarthritis. A population-based cohort study. Osteoarthritis Cartilage 2009;17:168-73.
49. Bagge E, Bjelle A, Eden S, et al. Factors associated with radiographic osteoarthritis: results from the population study 70-year-old people in Goteborg. J Rheumatol 1991;18:1218-22.

50. Haugen IK, Ramachandran VS, Misra D, et al. Hand osteoarthritis in relation to mortality and incidence of cardiovascular disease: data from the Framingham Heart Study. Ann Rheum Dis 2013;7474-81.

51. Sowers M, Karvonen-Gutierrez CA, Palmieri-Smith R, et al. Knee osteoarthritis in obese women with cardiometabolic clustering. Arthritis Rheum 2009;61:1328-36.

52. Visser W, den Heijer M, Spoelman W, et al. Glucose and insulin concentration in association with hand osteoarthritis: the NEO study. EULAR Congress; 2013;Abstract SAT0350.

53. Visser AW, de Mutsert $\mathrm{R}$, le Cessie $\mathrm{S}$, et al. The relative contribution of mechanical stress and systemic processes in different types of osteoarthritis: the NEO study. Ann Rheum Dis 2014. Published Online First

54. Philbin EF, Ries MD, Groff GD, et al. Osteoarthritis as a determinant of an adverse coronary heart disease risk profile. J Cardiovasc Risk 1996;3:529-33.

55. Ladjimi A, Youssef S, Chamakhi S, et al. [Rheumatologic manifestations in diabetes]. Tunis Med 1985;63:213-19.

56. Denko CW, Boja B, Moskowitz RW. Growth promoting peptides in osteoarthritis and diffuse idiopathic skeletal hyperostosis-insulin, insulin-like growth factor-I, growth hormone. J Rheumatol 1994;21:1725-30.

57. Nieves-Plaza M, Castro-Santana LE, Font YM, et al. Association of hand or knee osteoarthritis with diabetes mellitus in a population of Hispanics from Puerto Rico. J Clin Rheumatol 2013;19:1-6.

58. Cimmino MA, Cutolo M. Plasma glucose concentration in symptomatic osteoarthritis: a clinical and epidemiological survey. Clin Exp Rheumatol 1990;8:251-7.

59. Lindberg $\mathrm{H}$, Nilsson BE. Coinciding morbidity in patients with coxarthrosis. An epidemiological study of roentgen examinations. Arch Orthop Trauma Surg 1985;104:82-4.

60. Dequeker J, Burssens A, Bouillon R. Dynamics of growth hormone secretion in patients with osteoporosis and in patients with osteoarthrosis. Horm Res 1982;16:353-6.

61. Rahman MM, Kopec JA, Cibere J, et al. The relationship between osteoarthritis and cardiovascular disease in a population health survey: a cross-sectional study. BMJ Open 2013;3:pii: e002624

62. Wang S, Ganguli AX, Macaulay D, et al. The economic burden of osteoarthritis in Americans: analysis from a privately insured population. ACR Congress; 2013.

63. Horn CA, Bradley JD, Brandt KD, et al. Impairment of osteophyte formation in hyperglycemic patients with type II diabetes mellitus and knee osteoarthritis. Arthritis Rheum 1992;35:336-42.

64. Yoshimura N, Muraki S, Oka H, et al. Accumulation of metabolic risk factors such as overweight, hypertension, dyslipidaemia, and impaired glucose tolerance raises the risk of occurrence and progression of knee osteoarthritis: a 3-year follow-up of the ROAD study. Osteoarthritis Cartilage 2012;20:1217-26.

65. Eymard F, Parsons C, Edwards $\mathrm{MH}$, et al. Diabetes is a risk factor for knee osteoarthritis progression. Osteoarthritis Cartilage 2015. Published Online First: 3 February 2015.

66. Sellam J, Berenbaum F. Is osteoarthritis a metabolic disease? Joint Bone Spine 2013;80:568-73.

67. Schett G, Kleyer A, Perricone C, et al. Diabetes is an independent predictor for severe osteoarthritis: results from a longitudinal cohort study. Diabetes Care 2013;36:403-9.

68. Laiguillon MC, Courties A, Houard X, et al. Characterization of diabetic osteoarthritic cartilage and role of high glucose environment on chondrocyte activation: toward pathophysiological delineation of diabetes mellitus-related osteoarthritis. Osteoarthritis Cartilage Published Online First: 15 May 2015. doi:10.1016/j.joca.2015.04.026

69. Berenbaum F, Eymard F, Houard X. Osteoarthritis, inflammation and obesity. Curr Opin Rheumatol 2013;25:114-18.

70. Okazaki K, Jingushi S, Ikenoue $\mathrm{T}$, et al. Expression of insulin-like growth factor I messenger ribonucleic acid in developing osteophytes in murine experimental osteoarthritis and in rats inoculated with growth hormone-secreting tumor. Endocrinology 1999;140:4821-30.

71. Massicotte F, Fernandes JC, Martel-Pelletier J, et al. Modulation of insulin-like growth factor 1 levels in human osteoarthritic subchondral bone osteoblasts. Bone 2006;38:333-41. 